\title{
Digging for and grabbing the answers: novel whole-ecosystem approach quantifies damage and reveals mechanisms of invader-driven habitat destruction
}

\author{
Patrik Kraufvelin
}

Received: 24 August 2013 / Accepted: 30 August 2013 / Published online: 25 September 2013

(C) Springer-Verlag Berlin Heidelberg 2013

The feature article by Garbary et al. (2013), reporting damage of eelgrass beds (Zostera marina) due to digging and foraging activities of invasive European green crabs (Carcinus maenas), reminds me of some own recent experiences of this phenomenon, achieved within a mesocosm experiment at Solbergstrand in southeastern Norway in 2012 (Christie and Kraufvelin unpubl., see Kraufvelin et al. 2010 for a description of the mesocosms). Focusing on combined effects of nutrient enrichment and mesopredator release (due to overfishing of top predators) on rocky shore ecosystems, we also included sediment trays with eelgrass only to discover that numerous of our "gardened" eelgrass individuals were effectively eradicated by green crabs during the course of the experiment (within a few months). In comparison with the scenario described by Garbary et al. (2013), however, the damage in the mesocosms was marginal, despite causing complete disappearance from some trays and some mesocosm treatments, because not only it took place in artificial ecosystems but also happened in the native region of the crab (Fig. 1).

Among seven major threats to biodiversity, Primack (2008) characterizes invasion of exotic species as the most dramatic one, mainly due to its irreversible nature: it is almost impossible to get rid of an invasive species, once it has become established! Moreover, among the six other

Communicated by U. Sommer.

P. Kraufvelin

Environmental and Marine Biology, Department of Biosciences,

Åbo Akademi University, Artillerigatan 6, 20520 Turku, Finland

P. Kraufvelin $(\square)$

Novia University of Applied Sciences, Raseborgsvägen 9,

10600 Ekenäs, Finland

e-mail: patrik.kraufvelin@abo.fi major threats listed by Primack (2008), we also find three threats dealing with habitats, i.e., habitat destruction, habitat fragmentation and habitat degradation, and this should place the severity of the problem described by Garbary et al. (2013) into context. In the Canadian Maritime provinces (Garbary and Miller 2006; Malyshev and Quijón 2011), green crabs are having major negative impact on valuable eelgrass beds with still unforeseen consequences in the form of biodiversity loss and altered food webs, ecosystem functions and ecosystem services (e.g., Short and Wyllie-Echeverria 1996; Orth et al. 2006).

Previously, in another recent feature article in Marine Biology by Harley et al. (2013), we could acquaint ourselves with the case of Littorina littorea in the northeastern Pacific, a not yet established introduction, but still one which could impose negative impact on habitat-forming species (Díaz et al. 2012; Kraufvelin 2013). In the study by Garbary et al. (2013), the consequences of a successful species introduction are easier to grab, although their feature article merely focuses on proving that the crabs are causing the damage and on demonstrating the mechanisms and quantifying the various processes of eelgrass loss. To accomplish this, they used a novel whole-ecosystem approach, very rarely encountered in the marine literature (but see Kraufvelin et al. 2002). Garbary et al. (2013) conducted their study at only one site (see their text for justifications) in 2002, and it basically consisted of classification of eelgrass shoot types in wrack on the shore and determination of the following: shoot density in the water, accumulation of shore wrack, crab abundance, crab damage on eelgrass in cages and the amount of bare patch formation by crabs. Additionally, the authors used mark-recapture experiments on eelgrass, both on the shore and in the water, to further estimate the rate of eelgrass decline. Summarizing all their exploratory and experimental efforts, they have 


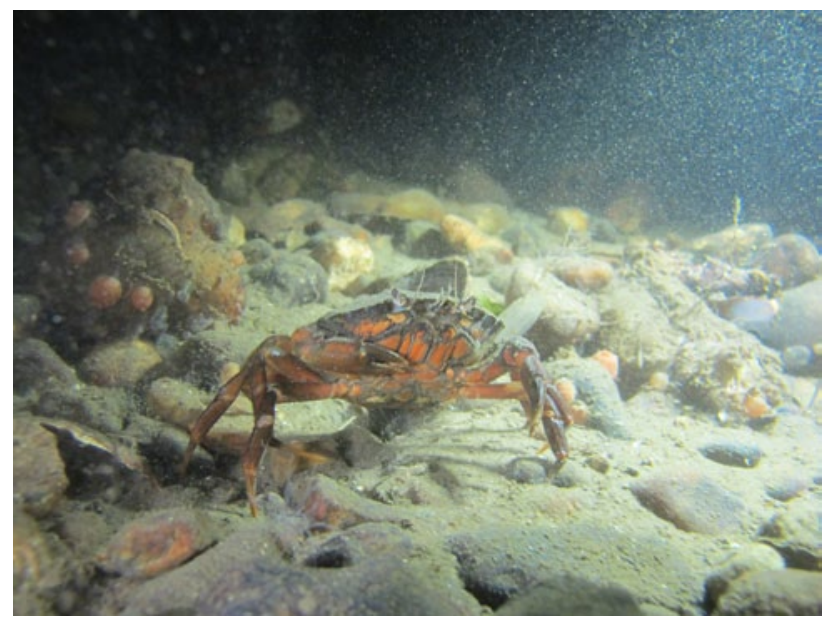

Fig. 1 The European green crab (Carcinus maenas) within its native distributional range in southern Norway (Photo: Janne Gitmark)

ended up with a thorough and reliable picture, quantifying the severe impact that green crabs can have on intact, natural eelgrass beds, while also simultaneously contributing with many methodological improvements, which presumably are of great interest for other researchers.

Thus, while the introduced crabs were digging for and grabbing their prey, mainly soft-shell clams Mya arenaria, and at the same time damaging the native eelgrass beds, the authors were, with their own "digging and grabbing for the answers," efficiently converting their initial observations into novel and valuable scientific information about the process and its potentially disastrous consequences. In my opinion, the paper by Garbary et al. (2013) is a scholarly example about the logical sequence of a research program, in which initial observations (of patterns in space and time) lead to models (explanations of theories), hypotheses (predictions based on models) and experiments (critical tests of null-hypotheses), which finally are interpreted (Underwood 1997), and then, one more puzzle piece in the giant puzzle of marine biological processes is put into its place. Finally, I also want to emphasize the inclusion of the epilogue/ postscript at the end of the article, i.e., a description of conditions of the study site during three revisits $(2005,2009$ and 2013) informing us about what happened after the researchers left and the lights went off.

\section{References}

Díaz ER, Kraufvelin P, Erlandsson J (2012) Combining gut fluorescence technique and spatial analysis to determine Littorina littorea grazing dynamics in nutrient-enriched and nutrient-unenriched littoral mesocosms. Mar Biol 159:837-852

Garbary DJ, Miller AG (2006) Green crabs (Carcinus maenas) as the grim reaper: destruction of eelgrass beds in Nova Scotia. J Shellfish Res 25:728

Garbary DJ, Miller AG, Williams J, Seymour NR (2013) Drastic decline of an extensive eelgrass bed in Nova Scotia due to the activity of the invasive green crab (Carcinus maenas). Mar Biol. doi: 10.1007/s00227-013-2323-4

Harley CDG, Anderson KM, Lebreton CA-M, MacKay A, AyalaDiaz M, Chong SL, Pond LM, Amerongen Maddison JH, Hung BHC, Iversen SL, Wong DCM (2013) The introduction of Littorina littorea to British Columbia, Canada: potential impacts and the importance of biotic resistance by native predators. Mar Biol 160:1529-1541

Kraufvelin P (2013) Pending possible establishment of Littorina littorea in the Pacific: to know the remedy, know thine enemy. Mar Biol 160:1525-1527

Kraufvelin P, Christie H, Olsen M (2002) Littoral macrofauna (secondary) responses to experimental nutrient addition to rocky shore mesocosms and a coastal lagoon. Hydrobiologia 484:149-166

Kraufvelin P, Lindholm A, Pedersen MF, Kirkerud LA, Bonsdorff E (2010) Biomass, diversity and production of rocky shore macroalgae at two nutrient enrichment and wave action levels. Mar Biol 157:29-47

Malyshev A, Quijón P (2011) Disruption of essential habitat by a coastal invader: new evidence of the effects of green crabs on eelgrass beds. ICES J Mar Sci 68:1852-1856

Orth RJ, Carruthers TJB, Dennison WC, Duarte CM, Fourqurean JW, Heck KL, Hughes AR, Kendrick GA, Kenworthy WJ, Olyarnik S, Short FT, Waycott M, Williams SL (2006) A global crisis for seagrass ecosystems. Bioscience 56:987-996

Primack RB (2008) A primer of conservation biology, 4th edn. Sinauer, Sunderland, MA

Short FT, Wyllie-Echeverria S (1996) Natural and human-induced disturbance of seagrasses. Environ Conserv 23:17-27

Underwood AJ (1997) Experiments in ecology: their logical design and interpretation using analysis of variance. Cambridge University Press, Cambridge 